Egyptian Journal of Aquatic Biology \& Fisheries

Zoology Department, Faculty of Science,

Ain Shams University, Cairo, Egypt.

ISSN $1110-6131$

Vol. 24 (6): 15- 24 (2020)

www.ejabf.journals.ekb.eg

\title{
Effect of location and grilling process on heavy metals concentration in muscles of different fish species, Egypt
}

\author{
Sayed M. Ibrahim*, Shaban A. El-Sherif, Safwat Abdel-Ghafour,Abdel-Rahman S. Abou \\ zied, Hassan M. Rabea, Adel A. El-Lahamy, Haitham M. El-Sayed and Kamel S. Abo-Zeid
}

Fish processing Technology Lab., Fisheries Division, National Institute of Oceanography and Fisheries (NIOF), Egypt.

*Corresponding Author: Ibrahim_niof@yahoo.com

\section{ARTICLE INFO \\ Article History: \\ Received: May 17, 2020 \\ Accepted: Aug. 20, 2020 \\ Online: Aug. 24, 2020}

Keywords:

Heavy metals,

Nile River,

lakes,

lagoons,

fish,

grilling.

\section{ABSTRACT}

This study aims to investigate the heavy metals concentrations in muscles of three raw fish species; mullet (Mugil cephalus), Nile tilapia (Oreochromis niloticus) and catfish (Clarias gariepinus) obtained from four different locations; the Nile River and Lakes of Wadi El-Rayan, Edku and Burullus during July 2019, and to study the effect of common grilling technique on their concentration in Nile tilapia samples as abundant fish. 17 elements were determined in fish muscles by ICP-OES Agilent 5100 VDV. Results revealed that the concentrations of heavy metals in fish species based on location were taken the following order; Burullus $>$ Nile River $>$ Wadi El-Rayan $>$ Edku. Whereas they were tilapia $>$ catfish $>$ mullet of Nile River, mullet $>$ tilapia $>$ catfish of Wadi El-Rayan, catfish $>$ tilapia $>$ mullet of Edku and catfish $>$ tilapia $>$ mullet fish of Burullus. The grilling process reduced the heaviest metals concentrations in tilapia species compared to raw samples. In conclusion, the heaviest metals in the muscles of fish species were lower than the maximum permissible limits set by International and Egyptian Standard Specifications and Legislations of food. Also, the grilling technique is an appropriate method to reduce the harmful effect of some heavy metals.

\section{INTRODUCTION}

Since last decades in Egypt, northern lagoons and lakes are suffering many problems; pollution, agricultural reclamation and some illegal human anthropogenic. Nowadays, cleanup processes for many Lakes and lagoons has been occurred by Egyptian Government to overcome pollutants and reduce fish gap. El-Ghobashy $\boldsymbol{e t}$ al . (2001) found that the values of $\mathrm{Zn}, \mathrm{Cu}, \mathrm{Fe}, \mathrm{Cd}$ and $\mathrm{Pb}$ in muscle tissue of Nile tilapia collected from Lake Burullus were 41.3, 2.18, 30.3, 0.03 and $0.22 \mu \mathrm{g} / \mathrm{g}$, respectively. Farag (2002) showed that the concentrations of $\mathrm{Zn}, \mathrm{Cu}, \mathrm{Fe}$ and $\mathrm{Pb}$ in muscle tissue of Nile tilapia caught from Lake Burullus were $7.97,2.38,10.37$ and $0.27 \mu \mathrm{g} / \mathrm{g}$ dry wt., respectively. Mourad et al. (2010) reported that the concentration of heavy metals (Cd, 
$\mathrm{Pb}$ and $\mathrm{Ni}$ ) were often above the maximum permissible limits according to FAO standards in fish species samples obtained from the River Nile, Manzala, Mariut, Edku, Burullus, Bardawil, Qarun and Wadi El-Rayan Lakes. In contrast, many authors decided the levels of $\mathrm{Zn}, \mathrm{Cu}, \mathrm{Fe}, \mathrm{Mn}$ and $\mathrm{Hg}$ were within acceptable limits; Abd-Allah (2013) found that the tilapia muscles from Nile River contained $\mathrm{Fe} 3.76, \mathrm{Zn} \mathrm{5.09,} \mathrm{Pb} 2.68, \mathrm{Cr} 0.26$, $\mathrm{Cu}$ 1.51, Cd 0.04, Co 0.23 and $\mathrm{Hg} 0.91 \mathrm{ppm}$ (ww). Saeed (2013) reported that the concentrations of heavy metals in tilapia muscles obtained from Edku lake were $0.28 \mathrm{Cd}$, $0.92 \mathrm{pb}, 47.88 \mathrm{Fe}, 2.62 \mathrm{Cu}, 29.22 \mathrm{Zn}$ and 2.78 Mn (ppm, dw). Younes et al. (2012) found that the concentrations of $\mathrm{Cd}, \mathrm{Cu}$ and $\mathrm{Pb}$ were $0.31-1.25,1.4-4.12$ and $5.75-27.35$ $\mu \mathrm{g} / \mathrm{g}$, respectively in muscles of tilapia obtained from Burullus Lake. Ibrahim et al. (2013) showed that the concentrations of heavy metals in raw Tilapia zillii and Eel (Anguella anguella) muscles obtained from Lake Qarun were 0.223 and $0.285 \mathrm{Cu}, 3.768$ and 3.52 $\mathrm{Pb}, 7.95$ and $8.04 \mathrm{Cr}, 7.07$ and $19.31 \mathrm{Zn}, 6.235$ and $6.74 \mathrm{Ni}, 0.173$ and 0.085 $\mathrm{Cd}$, and 41.428 and $3.133 \mathrm{Fe}$ (ppm), respectively. Basiouny (2018) showed the annual means of heavy metals in muscles of Nile tilapia collected from Lake Burullus were $\mathrm{Fe}$ (20.56), Mn (0.51), Cu (0.55), Zn (4.70), Ni (0.25), Cd (0.02) and Pb (0.17) $\mu \mathrm{g} / \mathrm{g}$.

On the other hand, fish are usually cooked by different ways before consumption (boiling, baking, roasting, frying and grilling) to enhance their flavor and taste then increase shelf life (Garcia-Arias et al., 2003), and to reduce the risk of pollutants in fish (Ersoy et al., 2003 and Ganbi, 2010). El-Sherif et al. (2016) showed that grilling process led to reduce all heavy metals values in all fish samples obtained from Wadi ElRayan Lake. Also, El-Sherif (2017) reported that all heavy metals in different fish species obtained from Wadi El-Rayan were lower than the permissible limit, and boiling reduced all determined heavy metals followed by grilling, while frying increased most of them.Therefore, this work was planned to investigate of heavy metals concentrations in muscles of three raw fish species; mullet (Mugil cephalus), Nile tilapia (Oreochromis niloticus) and catfish (Clarias gariepinus) obtained from four different locations; the Nile River and Lakes of Wadi El-Rayan, Edku and Burullus during July, 2019 besides to study the effect of common grilling technique on their concentration in Nile tilapia samples as abundant fish.

\section{MATERIALS AND METHODS}

\section{Study locations}

The Nile River and Lakes of Wadi El-Rayan, Edku and Burullus were selected to obtain similar fish species at the same time.

\section{Fish species}

Randomized three fish species; Nile tilapia (Oreochromis niloticus), mullet (Mugil cephalus), catfish (Clarias gariepinus) samples were obtained from different locations; Nile River and Lakes of Wadi El-Rayan, Edku and Burullus during July, 2019. They were transferred to Fish Processing Technology Lab., National Institute of Oceanography and Fisheries (NIOF) in Alex., Egypt using ice box. All samples (first batch) were carefully washed with tap water and drained. Second batch; Nile tilapia samples obtained from the pre-mentioned locations were rolled with wheat bran and common grilled on hot plate at $170^{\circ} \mathrm{C}$ for 20 min. Two batches; muscles of raw fish 
samples and grilled Nile tilapia were minced, dried at $70{ }^{\circ} \mathrm{C}$ till constant weight was obtained, grinded as a fine powder and packed in polyethylene bags till analysis.

\section{Analytical methods}

One gram fish muscles powder was taken and $10 \mathrm{ml} \mathrm{Nitric} \mathrm{acid} \mathrm{(65 \%} \mathrm{conc.),} 2 \mathrm{ml}$ $\mathrm{H}_{2} \mathrm{O}_{2}$ and $1 \mathrm{ml}$ deionized water were added and then digested using hot plate till a clear color was obtained. Clear samples were filtered using Whatman No. 42 filter paper, made up $25 \mathrm{ml}$ measuring flask with deionized water. 17 elements $(\mathrm{Cu}, \mathrm{Cr}, \mathrm{Co}, \mathrm{Cd}, \mathrm{Ba}, \mathrm{B}, \mathrm{As}$, $\mathrm{Al}, \mathrm{Zn}, \mathrm{V}, \mathrm{Ti}, \mathrm{Se}, \mathrm{Pb}, \mathrm{Ni}, \mathrm{Mo}, \mathrm{Mn}$ and Fe) were determined by ICP-OES Agilent 5100 VDV according to standard methods USEPA (method 2007 and USEPA Method 6010 C) in Central lab., NIOF (Alex.). All results were expressed as mean values $\mathrm{mg} \backslash \mathrm{kg}$ sample (ppm, dry weight).

\section{RESULTS}

\section{Effect of location on heavy metals concentrations in fish muscles}

Table (1) shows the concentration of heavy metals (ppm, dw) in some fish samples obtained from the Nile River during July, 2019. High values of studied elements were $\mathrm{Cu}, \mathrm{Cr}, \mathrm{Co}, \mathrm{Ba}, \mathrm{B}, \mathrm{As}, \mathrm{Al}, \mathrm{Zn}, \mathrm{V}, \mathrm{Ti}, \mathrm{Ni}, \mathrm{Mo}, \mathrm{Mn}$ and $\mathrm{Fe}$ in tilapia muscles, Cd and $\mathrm{Pb}$ in catfish and $\mathrm{Se}$ in mullet muscles. Also, the high values were $12.24 \mathrm{ppm} \mathrm{Al}$, in tilapia and $0.52 \mathrm{ppm} \mathrm{Pb}$ in catfish and $0.81 \mathrm{ppm} \mathrm{Se}$ in mullet muscles. Whereas, low values of elements were $<0.012 \mathrm{ppm} \mathrm{Cd}$ in mullet and tilapia, $<0.02 \mathrm{ppm}$ in mullet and catfish, and $<0.23 \mathrm{ppm} \mathrm{Pb}$ in mullet muscles.

Table 1. Concentration of heavy metals (ppm, dw) in some raw fish samples obtained from the Nile River during July, 2019.

\begin{tabular}{|c|c|c|c|c|c|c|c|c|c|c|c|c|c|c|c|c|c|}
\hline \multirow{2}{*}{ Fish spp. } & \multicolumn{17}{|c|}{ Concentrations of heavy metals (ppm) } \\
\hline & $\mathbf{C u}$ & $\mathrm{Cr}$ & Co & Cd & Ba & B & As & Al & $\mathbf{Z n}$ & $\mathbf{V}$ & $\mathbf{T i}$ & Se & $\mathbf{P b}$ & $\mathbf{N i}$ & Mo & Mn & $\mathbf{F e}$ \\
\hline Mullet & 0.13 & 0.88 & 0.01 & $<0.012$ & 0.03 & 0.82 & $<0.02$ & 7.29 & 3.61 & 0.01 & 0.06 & 0.81 & $<0.023$ & 0.51 & 0.09 & 0.14 & 6.00 \\
\hline Tilapia & 0.20 & 1.54 & 0.02 & $<0.012$ & 0.06 & 1.86 & 1.73 & 12.24 & 3.99 & 0.03 & 0.11 & 0.75 & 0.04 & 0.86 & 0.16 & 0.26 & 9.57 \\
\hline Catfish & 0.16 & 0.97 & 0.01 & 0.02 & 0.03 & 0.57 & $<0.02$ & 7.67 & 2.66 & 0.02 & 0.04 & 0.74 & 0.52 & 0.56 & 0.1 & 0.14 & 6.62 \\
\hline *MPLs & 20 & 1 & -- & 0.5 & .- & -- & -- & -- & 40 & -- & .- & -- & 2 & 0.4 & .- & $2-9$ & 30 \\
\hline
\end{tabular}

*MPLs: Maximum Permissible levels (Egyptian Organization for Standardization and Quality, 2005; Food and Agricultural Organization/World Health Organization, 1999; FAOIWHO, 1989 and FAO, 1983).

The concentration of heavy metals (ppm, dw) in some fish samples obtained from Wadi El-Rayan Lake during summer, 2019 are shown in Table (2). High values of elements were $\mathrm{Cu}, \mathrm{Cr}, \mathrm{Co}, \mathrm{B}, \mathrm{As}, \mathrm{Al}, \mathrm{Se}, \mathrm{Ni}, \mathrm{Mo}, \mathrm{Mn}$ and Fe in mullet muscles, Ba, Zn, $\mathrm{Ti}$ and $\mathrm{Pb}$ in tilapia and $\mathrm{Cd}$ in catfish muscles. Although mullet samples were highly polluted than tilapia and catfish samples however, values of some elements were lowered.

Heavy metals (ppm, dw) insome fish samples obtained from Edku Lagoon during July, 2019 are tabulated in Table (3). High values of elements were $\mathrm{As}, \mathrm{Pb}$ and $\mathrm{Mn}$ in mullet muscles and $\mathrm{B}$, Se and $\mathrm{Cu}$ in tilapia, while $\mathrm{Cr}, \mathrm{Co}, \mathrm{Al}, \mathrm{Zn}, \mathrm{Ni}, \mathrm{Mo}$ and $\mathrm{Fe}$ in catfish muscles. All fish muscles contained equal values of $<0.012 \mathrm{ppm} \mathrm{Cd}, 0.03 \mathrm{ppm} \mathrm{Ba}$ and $0.01 \mathrm{ppm} \mathrm{V}$ elements. 
Table 2. Concentration of heavy metals (ppm, dw) in some raw fish samples obtained from Wadi El-Rayan Lake during July, 2019.

\begin{tabular}{|c|c|c|c|c|c|c|c|c|c|c|c|c|c|c|c|c|c|}
\hline \multirow{2}{*}{ Fish spp. } & \multicolumn{17}{|c|}{ Concentrations of heavy metals (ppm); } \\
\hline & $\mathbf{C u}$ & $\mathbf{C r}$ & Co & Cd & Ba & B & As & Al & $\mathbf{Z n}$ & $\mathbf{V}$ & Ti & Se & $\mathbf{P b}$ & $\mathbf{N i}$ & Mo & Mn & $\mathbf{F e}$ \\
\hline Mullet & 0.21 & 1.10 & 0.02 & $<0.012$ & 0.03 & 0.87 & 0.04 & 8.72 & 2.09 & 0.01 & 0.05 & 0.73 & $<0.023$ & 0.61 & 0.12 & 0.15 & 8.34 \\
\hline Tilapia & 0.17 & 0.77 & 0.01 & $<0.012$ & 0.04 & 0.60 & $<0.02$ & 6.88 & 5.55 & 0.01 & 0.07 & 0.70 & 0.05 & 0.45 & 0.08 & 0.13 & 6.35 \\
\hline Catfish & 0.10 & 0.62 & 0.01 & 0.27 & 0.03 & 0.65 & $<0.02$ & 5.09 & 2.24 & 0.01 & 0.03 & 0.65 & $<0.023$ & 0.36 & 0.06 & 0.11 & 4.52 \\
\hline *MPLs & 20 & 1 & -- & 0.5 & -- & -- & -- & -- & 40 & -- & -- & -- & 2 & 0.4 & -- & $2-9$ & 30 \\
\hline
\end{tabular}

*MPLs: Maximum Permissible levels (Egyptian Organization for Standardization and Quality, 2005; Food and Agricultural Organization/World Health Organization, 1999; FAOIWHO, 1989 and FAO, 1983).

Table 3. Concentration of heavy metals ( $\mathrm{ppm} \mathrm{dw}$ ) in some raw fish samples obtained from Edku Lake during July, 2019.

\begin{tabular}{lccccccccccccccccc}
\hline \multirow{2}{*}{ Fish spp. } & \multicolumn{1}{c}{$\mathrm{Cu}$} & $\mathrm{Cr}$ & $\mathrm{Co}$ & $\mathrm{Cd}$ & $\mathrm{Ba}$ & $\mathrm{B}$ & $\mathrm{As}$ & $\mathrm{Al}$ & $\mathrm{Zn}$ & $\mathrm{V}$ & $\mathrm{Ti}$ & $\mathrm{Se}$ & $\mathrm{Pb}$ & $\mathrm{Ni}$ & $\mathrm{Mo}$ & $\mathrm{Mn}$ & $\mathrm{Fe}$ \\
\hline Mullet & 0.20 & 0.67 & 0.01 & $<0.012$ & 0.03 & 1.24 & 0.05 & 4.74 & 1.08 & 0.01 & 0.02 & 0.69 & 0.05 & 0.37 & 0.07 & 0.17 & 4.53 \\
Tilapia & 0.23 & 0.85 & 0.01 & $<0.012$ & 0.03 & 1.34 & $<0.02$ & 5.37 & 1.15 & 0.01 & $<0.015$ & 0.73 & 0.04 & 0.44 & 0.08 & 0.16 & 5.31 \\
Catfish & 0.19 & 1.14 & 0.02 & $<0.012$ & 0.03 & 1.02 & $<0.02$ & 7.68 & 1.51 & 0.01 & 0.02 & 0.65 & $<0.023$ & 0.64 & 0.11 & 0.15 & 6.29 \\
*MPLs & 20 & 1 & -- & 0.5 & -- & -- & -- & -- & 40 & -- & -- & -- & 2 & 0.4 & -- & $2-9$ & 30 \\
\hline
\end{tabular}

*MPLs: Maximum Permissible levels (Egyptian Organization for Standardization and Quality, 2005; Food and Agricultural Organization/World Health Organization, 1999; FAOIWHO, 1989 and FAO, 1983).

Table (4) exhibits the concentration of heavy metals (ppm, dw) in some fish samples obtained from Burullus Lagoon during July, 2019. High values of elements were $\mathrm{Cu}, \mathrm{Cr}, \mathrm{Co}, \mathrm{Al}, \mathrm{Zn}, \mathrm{Ni}, \mathrm{Mo}, \mathrm{Mn}$ and $\mathrm{Fe}$ in catfish muscles, B, As and $\mathrm{Se}$ in tilapia and $\mathrm{Ba}$ and $\mathrm{Pb}$ in mullet muscles. However, low values of elements were $\mathrm{Cu}, \mathrm{Cr}, \mathrm{Co}, \mathrm{Al}, \mathrm{Ni}, \mathrm{Mo}$, $\mathrm{Mn}$ and $\mathrm{Fe}$ in mullet, $\mathrm{Ba}, \mathrm{Zn}$ and $\mathrm{Pb}$ in tilapia $\mathrm{Se}$ as in catfish muscles. Also, all fish muscles contained equal values of $<0.012 \mathrm{ppm} \mathrm{Cd}, 0.01 \mathrm{ppm} \mathrm{V}$ and Ti elements.

Table 4. Concentration of heavy metals (ppm, dw) in some raw fish samples obtained from Burullus Lake during July, 2019.

\begin{tabular}{lcccccccccccccccccc}
\hline \multirow{2}{*}{$\begin{array}{l}\text { Fish } \\
\text { spp. }\end{array}$} & \multicolumn{1}{c}{ Cu } & Cr & Co & Cd & Ba & B & As & Al & Zn & V & Ti & Se & Pb & Ni & Mo & Mn & Fe \\
\hline Mullet & 0.18 & 0.42 & 0.01 & $<0.012$ & 0.06 & 0.95 & 0.06 & 3.12 & 1.5 & 0.01 & 0.02 & 0.68 & 0.06 & 0.23 & 0.04 & 0.09 & 3.07 \\
Tilapia & 0.19 & 0.89 & 0.02 & $<0.012$ & 0.02 & 1.11 & 0.12 & 6.23 & 1.1 & 0.01 & 0.02 & 0.69 & 0.03 & 0.52 & 0.1 & 0.13 & 4.89 \\
Catfish & 0.28 & 2.03 & 0.03 & $<0.012$ & 0.03 & 0.34 & 0.01 & 11.05 & 2.03 & 0.01 & $<0.015$ & 0.64 & 0.04 & 1.06 & 0.17 & 0.39 & 10.98 \\
$*$ MPLs & 20 & 1 & -- & 0.5 & -- & -- & -- & -- & 40 & -- & -- & -- & 2 & 0.4 & -- & $2-9$ & 30 \\
\hline
\end{tabular}

*MPLs: Maximum Permissible levels (Egyptian Organization for Standardization and Quality, 2005; Food and Agricultural Organization/World Health Organization, 1999; FAOIWHO, 1989 and FAO, 1983).

\section{Effect of grilling process on heavy metals concentrations}

Concerning the effect of grilling process on heavy metals in muscles of tilapia fish from different locations, the concentration of metals in raw and grilled fish samples are given in Table (5). By grilling, the values of some heavy metals were affected and others did not change. The values of $\mathrm{Cu} 0.20$, Ba 0.06, B 1.86, As 1.73, Al 12.24, Zn 3.99, V 0.03, Ti 0.11, Se 0.75, Pb 0.04, Ni 0.86, Mo 0.16, Mn 0.26 and Fe 9.57 (ppm, dw) of raw 
tilapia muscles from Nile River (Table, 1) were decreased to $0.12,0.03,<0.66,<0.02$, $10.39,2.4,0.01,0.05,0.70,<0.023,0.74,0.13,0.17$ and $7.50(\mathrm{ppm}, \mathrm{dw})$. Whereas, the values (ppm, dw) of Co $(0.02)$ and $\mathrm{Cd}(<0.012)$ did not affect by grilling. Values of $\mathrm{Cu}$, $\mathrm{Zn}, \mathrm{Se}$ and $\mathrm{Pb}$ in raw tilapia muscles from Wadi El-Rayan Lake (Table,2) were decreased, $\mathrm{Cr}, \mathrm{Co}, \mathrm{Ba}, \mathrm{B}, \mathrm{Al}, \mathrm{Ni}, \mathrm{Mo}, \mathrm{Mn}$ and Fe were increased however, $\mathrm{Cd}, \mathrm{As}, \mathrm{V}$ and Ti elements did not affect by grilling. Also, in raw tilapia muscles from Edku Lagoon, $\mathrm{Cd}, \mathrm{B}, \mathrm{Pb}$ and $\mathrm{Fe}$ concentration (Table, 3) were decreased by grilling, $\mathrm{Cr}, \mathrm{Ba}, \mathrm{As}, \mathrm{Al}, \mathrm{Zn}$, $\mathrm{Se}, \mathrm{Ni}$ and Mo were increased, but $\mathrm{Cu}, \mathrm{Se}, \mathrm{V}$ and Ti did not affect by grilling process.

Table 5. Concentration of heavy metals (ppm, $\mathrm{dw}$ ) in grilled tilapia muscles samples from different locations during July, 2019.

\begin{tabular}{|c|c|c|c|c|c|c|c|c|c|c|c|c|c|c|c|c|c|}
\hline \multirow{2}{*}{ Locations } & \multicolumn{17}{|c|}{ Concentrations of heavy metals (ppm); } \\
\hline & $\mathrm{Cu}$ & $\mathrm{Cr}$ & Co & Cd & $\mathbf{B a}$ & $\mathbf{B}$ & As & Al & $\mathbf{Z n}$ & $\mathbf{V}$ & $\mathbf{T i}$ & Se & $\mathbf{P b}$ & $\mathbf{N i}$ & Mo & Mn & $\mathbf{F e}$ \\
\hline Nile River & 0.12 & 1.3 & 0.02 & $\begin{array}{c}\mathbf{0 . 0 1 2} \\
\end{array}$ & 0.03 & 0.66 & $<0.02$ & 9.85 & 2.4 & 0.01 & 0.05 & 0.70 & $<0.023$ & 0.74 & 0.13 & 0.17 & 7.50 \\
\hline Wadi El-Rayan & 0.13 & 1.33 & 0.02 & $<0.012$ & 0.03 & 0.62 & $<0.02$ & 10.39 & 1.69 & 0.01 & 0.07 & 0.67 & 0.04 & 0.76 & 0.14 & 0.18 & 7.96 \\
\hline Edku & 0.23 & 0.89 & 0.01 & $<0.012$ & 0.04 & 1.08 & 0.03 & 6.42 & 1.18 & 0.01 & $<0.015$ & 0.77 & $<0.023$ & 0.51 & 0.1 & 0.20 & 5.21 \\
\hline Burullus & 0.14 & 0.66 & 0.01 & $<0.012$ & 0.02 & 1.75 & 0.06 & 4.63 & 1.09 & 0.01 & $<0.015$ & 0.72 & 0.03 & 0.37 & 0.07 & 0.13 & 4.77 \\
\hline *MPLs & 20 & 1 & -- & 0.5 & -- & -- & -- & -- & 40 & -- & -- & -- & 2 & 0.4 & -- & $2-9$ & 30 \\
\hline
\end{tabular}

*MPLs: Maximum Permissible levels (Egyptian Organization for Standardization and Quality, 2005; Food and Agricultural Organization/World Health Organization, 1999; FAOIWHO, 1989 and FAO, 1983).

In the same trend, the concentration of most investigated heavy metals in muscles of tilapia fish from Burullus Lake (Table, 4); values of $\mathrm{Cu}, \mathrm{Cr}, \mathrm{Co}, \mathrm{Ba}, \mathrm{Al}, \mathrm{Zn}, \mathrm{Ti}, \mathrm{Ni}, \mathrm{Mo}$ and $\mathrm{Fe}$ were decreased, while values of $\mathrm{B}, \mathrm{As}$ and $\mathrm{Se}$ were increased, but $\mathrm{Cd}, \mathrm{V}, \mathrm{Pb}$ and Mn did not affect by grilling process.

\section{DISCUSSION}

The results of heavy metals concentrations in Table (1) of mullet, tilapia and catfish muscles samples obtained from the Nile River during July, 2019 revealed that tilapia fish had high concentrations for most heavy metals followed by catfish and mullet fish. The higher values of common heavy metals; $\mathrm{Pb} 0.52$, Cd 0.02, Zn 3.99, Fe 9.57, Cu $0.20, \mathrm{Mn} 0.26$ (ppm, dw) in all investigated fish samples obtained from the Nile River were lower than the maximum permissible limits (MPLs) ( $\mathrm{Pb} 2, \mathrm{Cd} \mathrm{0.5,} \mathrm{Zn} \mathrm{40,} \mathrm{Fe} \mathrm{30,} \mathrm{Cu}$ 20, Mn 2-9, ppm) as set by Egyptian Organization for Standardization and Quality (EOS, 2005); Food and Agricultural Organization/World Health Organization (FAOIWHO, 1999). Ni element in all investigated fish samples was higher than MPLs (0.4 ppm) as set by FAO (1983) also, Cr element in tilapia fish samples was higher than MPLs $(1 \mathrm{ppm})$ as set by FAO (1983), but it was lower in mullet (0.88) and catfish $(0.97 \mathrm{ppm}$, $\mathrm{dw})$. Some of the detected heavy metals (Co, Ba, B, As, Al, V, Ti, Se and Mo) have no known MPLs. The obtained values of heavy metals in muscles of tilapia samples obtained from Nile River were lower than those reported by Abd-Allah (2013). However, our results are in agreement with foundings by Badr et al. (2014), they showed that the mean value of $\mathrm{Pb}$ in muscle samples of $O$. niloticus fish collected from two areas of River Nile were 0.662 and $0.833 \mathrm{ppm}$, while Cd values were 0.020 and $0.123 \mathrm{ppm}$. Hamada et al. (2018) observed that the mean value of $\mathrm{Cd}$ in small wild Nile tilapia muscles was $0.10 \mathrm{ppm}$, 
while it was $0.15 \mathrm{ppm}$ in large size fish. Helmy et al. (2018) reported that the values (ppm) of $\mathrm{Hg}, \mathrm{Pb}$ and $\mathrm{Cd}$ were $1.62,1.29,0.95$ in C. gariepinus, 0.67, 0.53, 0.36 in $O$. niloticus and $0.25,0.19,0.14 \mathrm{ppm}$ in $M$. cephalus collected from different fish markets in Kalyobia governorate, Egypt, respectively.

Wadi El-Rayan Lake, from data in Table (2), it could be found that the values of some heavy metals were ranged $<0.023-0.05 \mathrm{~Pb},<0.012-0.27 \mathrm{Cd}, 2.09-5.55 \mathrm{Zn}, 4.52$ - $8.34 \mathrm{Fe}, 0.10-0.21$ and $0.11-0.15$ (ppm, dw) in all investigated fish species. They were much less than MPLs. Ni element was higher value in mullet fish sample $(0.61$ ppm) and tilapia fish $(0.45 \mathrm{ppm})$ than MPL $(0.4 \mathrm{ppm})$, while it was lower than MPL for catfish $(0.36 \mathrm{ppm})$. Cr value was higher in mullet fish $(1.10 \mathrm{ppm})$ than MPL (1 ppm), while it was lower than MPL for tilapia fish $(0.77 \mathrm{ppm})$ and catfish $(0.62 \mathrm{ppm})$. This indicated that mullet was higher in most heavy metals than tilapia and catfish, respectively. However, all examined fish species from Wadi El-Rayan Lake were contained heavy metals lower than MPLs. These results are in agreement with that reported by Sayed and Abdel-Satar (2009); El-Sherif et al. (2016), they found that the levels of $\mathrm{Pb}, \mathrm{Cd}, \mathrm{Mn}, \mathrm{Cu}$ and $\mathrm{Zn}$ in all investigated fish samples from Wadi El-Rayan Lakes were lower than the MPLs (FAOIWHO, 1989). But these results were higher than reported by Abdou et al. (2016), they reported that $\mathrm{Pb}, \mathrm{Cd}, \mathrm{Mn}$ and $\mathrm{Cu}$ levels were 0.003 , $0.003,0.038$ and 0.014 ppm of Tilapia nilotica from Wadi El-Rayan Lake and they were 0.006, 0.002, 0.009 and $0.011 \mathrm{ppm}$, respectively of Claries lazera.

Edku lagoon, the results in Table (3) reveled that the concentrations of common heavy metals in mullet, tilapia and catfish from Edku Lake were much lower than MPLs. The concentrations (ppm) were 0.02-0.05 pb, <0.012 Cd, 1.08-1.51 Zn, 4.53-6.29 Fe, 0.19-0.23 $\mathrm{Cu}$ and 0.15-0.17 lower than MPLs. Ni element was higher in catfish (0.64 ppm) and tilapia fish (0.44 ppm) than MPLs while it was lower than MPL for mullet fish sample. Also, $\mathrm{Cr}$ was higher in catfish $(1.14 \mathrm{ppm})$ and tilapia fish $(0.85 \mathrm{ppm})$ than MPLs (1 ppm), while it was lower than MPLs for mullet fish sample (0.67 ppm). Catfish was higher of most heavy metals followed by tilapia and mullet fish. The concentrations of heavy metals in investigated fish species were lower than reported by Saeed (2013), he found that the concentrations ( $\mathrm{ppm}, \mathrm{dw}$ ) of the same heavy metals in tilapia obtained from Edku lake were $0.28 \mathrm{Cd}, 0.92 \mathrm{pb}, 47.88 \mathrm{Fe}, 2.62 \mathrm{Cu}, 29.22 \mathrm{Zn}$ and $2.78 \mathrm{Mn}$ compared to our results; $\mathrm{Cd}<0.012, \mathrm{~Pb} 0.04$, Fe 5.31, $\mathrm{Cu} 0.23, \mathrm{Zn} 1.15$ and $\mathrm{Mn} 0.16$ (ppm, dw). Also, our results were lower than those findings by El-Nemr et al. (2003), they found that the concentrations of heavy metals in summer of Tilapia zillii and Claris lazera from Edku lake were $1.36 \mathrm{Cd}, 0.89 \mathrm{Cu}, 517.65 \mathrm{Fe}, 0.86 \mathrm{Hg}, 17.21 \mathrm{Mn}$ and 29.87 $\mathrm{Zn}$ (ppm, dw) for Tilapia zillii and $1.65 \mathrm{Cd}, 1.04 \mathrm{Cu}, 460.98 \mathrm{Fe}, 0.16 \mathrm{Hg}, 16.14 \mathrm{Mn}$ and $42.68 \mathrm{Zn}$ (ppm, dw) in Claris lazera. This decrement in concentrations of some heavy metals in this study compared to others workers may be due to fish species, age, season, time of catch and cleanup processes occurred in some lakes.

Burullus lagoon, the concentrations of heavy metals in muscles of some fish species from Burullus (Table 4) revealed that most heavy metals were higher in catfish muscles (Cu 0.28, Cr 2.03, Co 0.03, Al 11 05, Zn 2.03, Ni 1.06, Mo 0.17, Mn 0.31 and $10.98 \mathrm{ppm}, \mathrm{dw}$ ) followed by tilapia (B 1.11, As 0.12, Se $0.69 \mathrm{ppm}$ ) and mullet fish (Ba $0.06, \mathrm{pb} 0.06 \mathrm{ppm})$, respectively. These results indicated that the common heavy metals $\mathrm{Pb}, \mathrm{Cd}, \mathrm{Zn}, \mathrm{Fe}, \mathrm{Cu}, \mathrm{Mn}$ ppm in all investigated fish species from Burullus were lower than MPLs in tables. Concentrations of Ni was higher in catfish (1.06 ppm) and tilapia fish (0. 
$52 \mathrm{ppm})$ than MPLs, while it was lower than MPLs for mullet fish sample (FAO, 1983). Also, concentration of $\mathrm{Cr}$ was higher in catfish (2.03 ppm) than MPL (1 ppm), while it was lower than MPL for tilapia fish $(0.89 \mathrm{ppm})$ and mullet fish sample $(0.42 \mathrm{ppm})$. These results were lower than those reported by El-Ghobashy et al. (2001), they found that the concentrations of $\mathrm{Zn}, \mathrm{Cu}, \mathrm{Fe}, \mathrm{Cd}$ and $\mathrm{pb}$ in tissues of Oreochromis niloticus collected from Burullus Lake were 41.3, 2.18, 30.3, 0.03 and $0.22 \mu \mathrm{g} / \mathrm{g} \mathrm{dw}$, respectively and Fathi et al. (2001), they reported that the concentrations of $\mathrm{Zn}, \mathrm{Cu}, \mathrm{Fe}$ and $\mathrm{Pb}$ in muscle tissue of Oreochromis niloticus caught from Burullus Lake were 7.97, 2.38, 10.37 and 0.27 $\mu \mathrm{g} / \mathrm{g} \mathrm{dw}$, respectively. Younes et al. (2012) showed the concentrations of $\mathrm{Cd}, \mathrm{Cu}$ and $\mathrm{Pb}$ in tilapia muscles samples collected from Burullus Lake were ranged from 0.31-1.25, 1.44.12 and 5.75-27.35 $\mu \mathrm{g} / \mathrm{g}$, respectively. Also, Basiouny (2018) found that annual mean of heavy metals in Oreochromis niloticus from Burullus Lake were Fe 20.56, Mn 0.51, Cu 0.55, Zn 4.70, Ni 0.25, Cd 0.02 and $\mathrm{Pb} 0.17 \mu \mathrm{g} / \mathrm{g}$.

Concerning the relation between collecting locations (Nile River, Lakes of Wadi El-Rayan, Edku and Burullus), for some fish species (mullet, tilapia and catfish) and concentrations of heavy metals in muscles of these fish. From the results and discussion, the concentrations of all heavy metals differed in all fish species based on location. The range of common heavy metals concentrations in different fish muscles of Nile River were $\mathrm{Cd}<0.012-0.02, \mathrm{~Pb}<0.023-0.52$, Zn 2.66-3.99, $\mathrm{Cu} 0.13-0.20$, Fe 6.00-9.57, Mn 0.14-0.26, Ni 0.51-0.86 and $\mathrm{Cr} 0.88-1.54 \mathrm{ppm}$. In Wadi El-Rayan Lake, it was $\mathrm{Cd}$ $<0.012-0.27, \mathrm{~Pb}<0.023-0.50$, Zn 2.09-5.55, Cu 0.10-0.21, Fe 4.52-8.34, Mn 0.11-0.15, Ni 0.36-0.61 and Cr 0.62-1.10 ppm. In Edku lagoon, it was $\mathrm{Cd}<0.012, \mathrm{~Pb}<0.02-0.05, \mathrm{Zn}$ 1.08-1.51, $\mathrm{Cu}$ 0.19-0.23, Fe 4.53-6.29, Mn 0.15-0.17, Ni 0.37-0.64 and $\mathrm{Cr} 0.67-1.14$ $\mathrm{ppm}$. And in Burullus lagoon, it was found that $\mathrm{Cd}<0.012$, $\mathrm{Pb} 0.03-0.06, \mathrm{Zn} 1.10-2.03$, $\mathrm{Cu} 0.18-0.28$, Fe 3.07-10.98, Mn 0.13-0.39, Ni 0.23-1.06 and Cr 0.42-2.03 ppm. This indicted that the concentrations of all heavy metals except $\mathrm{Ni}$ in raw muscles of fish species collected from Nile River and Lakes of Wadi El-Rayan, Edku and Burullus, $\mathrm{Cr}$ for tilapia (in the Nile River), for catfish (in Edku and Burullus Lakes) and for mullet (in Wadi El-Rayan Lake) were less than MPLs. As well as the difference in the concentration of heavy metals in the same species of fish obtained from different locations was low, also the same trend was found in different fish species. The concentrations of heavy metals in fish species based on location were taken the following order; Burullus $>$ Nile River $>$ Wadi El-Rayan $>$ Edku. Whereas they were tilapia $>$ catfish $>$ mullet of Nile River, mullet $>$ tilapia $>$ catfish of Wadi El-Rayan, catfish $>$ tilapia $>$ mullet of Edku and catfish $>$ tilapia $>$ mullet fish of Burullus.

Concerning the effect of grilling process on heavy metals in muscles of tilapia fish obtained from different locations; Nile River and Lakes of Wadi El-Rayan, Edku and Burullus, from data in Table (5), it could be observed that some heavy metals decreased, others increased and others did not affect by the grilling process. Also, it was found that $\mathrm{Ni}$ element sharply increased by grilling process. The reduction in trace metals concentrations as affected by grilling process may be due to the release of these metals with the loss of drip as free salts, possibly in association with soluble amino acids and uncoagulated proteins bounded with metals (Abd-Allah, 2013), while, the increase in some metals may be related to decrease in the moisture content that occur during grilling process (Ersoy $\boldsymbol{e t}$ al., 2006). These results are in accordance with reported by Ersoy and Ozeren (2009), $\mathrm{Mn}$ and $\mathrm{Zn}$ values of raw African catfish were 0.29 and $3.48 \mathrm{ppm}$ 
decreased to 0.25 and $3.43 \mathrm{ppm}$, respectively in grilled fish samples. Abd-Allah (2013) found that the loss rates of the investigated heavy metals ranged from 2.8 to $40.15 \%$ in grilled tilapia products. Also, the same trend of reduction most heavy metals by grilling was found by El-Sherif et al. (2016), they found the $\mathrm{Pb}$ concentration (ppm, ww) of raw Nile tilapia and mullet fish samples obtained from Wadi El-Rayan first Lake were 0.415 and $0.196 \mathrm{ppm}$ decreased to 0.373 and $0.145 \mathrm{ppm}$, respectively in grilled samples, $\mathrm{Cd}$ in raw Nile tilapia was $0.058 \mathrm{ppm}$ decreased to 0.034 in grilled samples, $\mathrm{Cu}$ in mullet fish fillets was 0.051 decreased to 0.016 in grilled samples also, $\mathrm{Zn}$ concentrations were 0.221 and $0.086 \mathrm{ppm}$ in raw Nile tilapia and mullet fish flesh and then decreased to 0.089 and 0.038 in grilled samples. Concerning MPLs, we found that the concentrations of $\mathrm{Pb}, \mathrm{Cd}$, $\mathrm{Zn}, \mathrm{Fe}, \mathrm{Cu}, \mathrm{Mn}$ and $\mathrm{Cr}$ in all investigated raw and grilled tilapia fish samples collected from different locations were lower than the MPLs in tables. The values of Ni element in all investigated raw and grilled tilapia fish samples collected from different locations were higher than the MPL (FAO, 1983), and Cr element was higher than MPL in raw and grilled tilapia fish obtained from the Nile River and grilled tilapia from Wadi El-Rayan Lake and lower other ones. Some of the detected heavy metals; Co, Ba, B, As, Al, V, Ti, Se and Mo have no known MPLs. These results are in agreement with found by Ersoy $\boldsymbol{e} \boldsymbol{t a l}$. (2006); Ersoy and Ozeren (2009); Diaconescu et al. (2012); Abdelhamid et al. (2016); El-Sherif (2017).

\section{CONCLUSION}

In conclusion, all common heavy metals in the muscles of fish species were lower than the maximum permissible limits set by International and Egyptian Standard Specifications and Legislations of food. Also, grilling technique is an appropriate method to reduce the harmful effect of some heavy metals.

\section{AKNOWLEDGEMENT}

All authors are grateful of National Institute of Oceanography and Fisheries for funding this work.

\section{REFERENCES}

Abd-Allah, Shimaa, S. (2013). Studies on chemical and microbiological contaminants in some fish species and the influence of some cooking and processing methods on these contaminants. M. Sc. Thesis, Fac. of Agric. AL-Azher Univ., Egypt.

Abdelhamid, A. M.; Emara, H. M. and Pekhet and Mona A. M. (2016). Reducing leadcontent in tilapia and mugile during preparing and cooking of fish. Sustainable Aquaculture Magazine, May 2016.

Abdou, K. A.; Sharkawy, A. B.; Manal, M. M.; Ehdaa, O. H. and Khadiga, I. A. (2016). Assessment of some environmental pollutants in Wadi El-Rayan Lake, Fayoum Governorate. Journal of Scientific and Engineering Research, 3 (3): 218-237. 
Badr, A. M.; Mahana, N. A. and Eissa, A. (2014). Assessment of heavy metal levels in water and their toxicity in some tissues of Nile Tilapia (Oreochromis niloticus) in River Nile basin at greater Cairo, Egypt. Global Veterinarian 13 (4): $432-443$.

Basiony, A. I. (2018). Environmental studies on heavy metals pollution and management of Lake Burullus, Egypt. Ph.D. Thesis, Faculty of Sci., Port-Said Univ., Port Said, Egypt.

Diaconescu, C.; Urdes, L.; Diaconescu, S. and Popa, D. (2012). Effects of cooking methods on the heavy metal concentrations in the fish meat originating from different areas of Danube River. Scientific Papers, Animal Science, Series D, Vol. LV 265-267.

El-Ghobashy, H. A.; Zaghloul, Kh. H. and Metwally, A. A. (2001). Effect of some water pollutants on the Nile tilapia Oreochromis niloticus collected from the River Nile and some Egyptian Lakes. Egyptian Journal of Aquatic Biology and Fisheries, 5(4):251-279.

El-Nabawy, A.; Heinzow, B. and Kruse, H. (1987). As, Cd, Cu, Pb, $\mathrm{Hg}$ and $\mathrm{Zn}$ in fish from Alexandria region. Egypt. Bull. Environ. Contam. Toxicol., 39: 889-897.

El-Nemr, A.; El-Sikaily, Amany and Khaled, Azza (2003). Heavy metals concentration in some fish tissues from South Mediterranean waters, Egypt. J. Aquat. Biol. \& Fish, 7 (3): 155 -172.

El-Sherif, S. A. (2017). Determination of some contaminants in silver carp and catfish flesh from Wadi El-Rayan Lake and the effect of traditional cooking methods on their concentrations. International Journal of Chem. Tech Research, 10(12): 143154.

El-Sherif, S. A.; Ibrahim, S. M. and Abdel-Ghafour, S. A. (2016). The validity of some dominant fishes obtained from Wadi El-Rayan Lakes for human consumption. Int. J. Adv. Res. 4(10): 1278-1285.

EOS (2005). Egyptian Organization for Standardization and Quality, Maximum residual limit of heavy metals in food. Ministry of Industry, No. 2360/2005, Cairo, Egypt.

Ersoy, B. and Ozeren, A. (2009): The effect of cooking methods on mineral and vitamin contents of African catfish. Food Chemistry, 115: 419 - 422.

Ersoy, B.; Yanar, Y.; Kü-ükgülmez, A. and Çelik, M. (2006). Effects of four cooking methods on the heavy metal concentrations of the sea bass fillets (Dicentrarchus labrax Linne, 1785). Food Chem. 99, 748-751.

FAO (1983). Compilation of legal limits for hazardous substances in fish and fishery products. FAO Fishery Circular, No. 464, pp: 5-100.

FAO/WHO (1999). Food Agriculture Organization/World Health Organization, Expert Committee on Food Additives. Summary and conclusions of the sixty-first meeting of the Joint FAO/WHO Expert Committee on Food Additives (JECFA). Rome, Page 15 of 22.

FAO/WHO (1989). Evaluation of certain food additives and the contaminants mercury, lead and cadmium. WHO Technical Report, Series No. 505.

Farag, M. El-S. (2002). Genetically and physiological studies on fish collected from polluted locations. Ph. D. Thesis, Faculty of Sciences, Zagazig University. 
Fathi, A. A.; Abd-Elzaher, H. M.; Flower, R.; Ramadani, M. and Kraiem, M. (2001). Wetland phytoplankton communities in North African Lakes: the Cass ARINA project. Aquatic Ecology, 35 (3-4): 303-318.

Ganbi, H. H. A. (2010). Heavy metals pollution level in marine Hammour fish and the effect of popular cooking methods and freezing process on these pollutants. World J. Dairy Food Sci., 5(2): 119-126.

Garcia-Arias, M. T.; Pontes, E. A.; Garcia-Linares, M. C.; Garcia-Fernandaz, M. C. and Sanchez-Muniz, F. J. (2003). Cooking-Freezing Reheating (CFR) of sardine (Sardina pilchardus) fillets. Effects of different cooking and reheating procedures on the proximate and fatty-acid compositions. Food Chem., 83:349356.

Hamada, M. G; Elbagouri, Z. A.; Khader, R. A. and Elbagory, A. M. (2018). Assessment of heavy metal concentration in fish meat of wild and farmed Nile tilapia (Oreochromis niloticus), Egypt. Alexandria Journal of Veterinary Sciences, 57 (1): 30-37.

Helmy, Nariman A.; Mohamed A. H.; Hassanien, Faten, S. and Ahmed A. M. (2018). Detection of heavy metals residues in fish and shellfish. Benha veterinary medical journal, vol. 34, no. 2: 255-264.

Ibrahim' S. M.; El-Sherif, S. A. and Abo-Taleb, M. (2013). Effect of grilling process on heavy metals concentrations in some fish muscles, Lake Qarun, Egypt. BBJ, $1(4): 1-5$.

Mourad, M.; Assem, H.; El-Saihia, M.; Khalifa, A. and Hassan, B. (2010). Human health risk assessment associated with current Egyptian dietary intakes of fish. Egyptian Journal of Aquatic Research, 36 (1):147-159.

Saeed, S. M. (2013): Impact of environmental parameters on fish condition and quality in Lake Edku, Egypt. Egypt. J. Aquat. Biol. \& Fish., Vol. 17, No. 1: 101-112.

Sayed, M. F. and Abdel-Satar, Amaal, M. (2009). Chemical assessment of Wadi ElRayan Lakes-Egypt. American-Eurasian J. Agric. \& Environ. Sci., 5 (1): 53-62.

Younes, E. M.; Radwan, A. M. and Ibrahim, S. M. (2012). Effect of seasonal variations on bioaccumulation of heavy metals in Nile tilapia (Oreochromis niloticus) from Lake Burullus, Egypt. Mansoura journal of Biology, 38 (1): 2129. 